\title{
GASTROPODS FROM THE SOLIMÕES FORMATION (UPPER MIOCENE), ACRE BASIN, BRAZIL
}

\author{
FELIPE NASCIMENTO SOUSA (D) \\ Programa de Pós-Graduação em Biociências - Interunidades - Assis/Bauru, Departamento \\ de Ciências Biológicas, Universidade Estadual Paulista, 17033-360, Bauru, SP, Brazil. \\ fn.sousa@unesp.br \\ RODRIGO CESAR MARQUES (D) \\ Departamento de Ciências Biológicas, Câmpus JK, Universidade Federal dos Vales \\ do Jequitinhonha e Mucuri, 39100-000, Diamantina, MG, Brazil. \\ marquesrc@yahoo.com.br
VICTOR RODRIGUES RIBEIRO @, GEOVANE AUGUSTO GAIA (1)
Programa de Pós-Graduação em Biociências, Interunidades, Assis/Bauru, Departamento de Ciências Biológicas, Universidade Estadual Paulista, 17033-360, Bauru, SP, Brazil. victor.gelufmt@gmail.com,geovane.gaia@unesp.br

\section{EDSON GUILHERME (D, ANDRÉA MACIENTE D, JONAS PEREIRA DE SOUZA-FILHO (D) Laboratório de Pesquisas Paleontológicas (LPP), Universidade Federal do Acre, 69920-900, Rio Branco, AC, Brazil. guilherme@ufac.br,andreamaciente@gmail.com,jpdesouzafilho@hotmail.com}

\author{
ANNIE SCHMALTZ HSIOU (D) \\ Laboratório de Paleontologia, Universidade de São Paulo, 14040-901, Ribeirão Preto, SP, Brazil. \\ anniehsiou@ffclrp.usp.br
}

\section{RENATO PIRANI GHILARDI (D)}

Programa de Pós-Graduação em Biociências - Interunidades - Assis/Bauru, Departamento de Ciências Biológicas, Universidade Estadual Paulista, 17033-360, Bauru, SP, Brazil. renato.ghilardi@unesp.br

\begin{abstract}
A taxonomic review of Miocene gastropods from the Solimões Formation, Acre Basin, Brazil, from specimens collected at Cachoeira do Bandeira, Oriente, and an outcrop named Spot 04, is here presented. Three ampullariid species (Pomacea maculata, $P$. planorbula, Pomacea sp.), one thiarid species (Aylacostoma sp.), and one cochliopid species (Sioliella sp.) are identified for these deposits. These gastropod are known to occur in freshwaters environments, thus consolidating the hypothesis of a non-influence of brackish water on the upper Miocene deposits of the Acre Basin. The previous identification of P. maculata and Aylacostoma sp. is changed here considering biometrical analyses and shell morphological descriptions. The first report of Sioliella in this basin increases the gastropod fauna known for these strata and expands the range of this genus.
\end{abstract}

Keywords: Pomacea, Aylacostoma, Sioliella, Ampullariidae, Thiaridae, Cochliopidae.

\begin{abstract}
RESUMO - Aqui é apresentada uma revisão taxonômica de gastrópodes do Mioceno da Formação Solimões, Bacia do Acre, Brasil, de espécimes coletados em Cachoeira do Bandeira, Oriente e de um afloramento chamado Ponto 04. Três espécies de ampularídeos (Pomacea maculata, P. planorbula e Pomacea sp.), uma espécie de Thiaridae (Aylacostoma sp.) e uma espécie de Cochliopidae (Sioliella sp.) são identificadas nesses depósitos e novas classificações são propostas. Esses grupos de gastrópodes são conhecidos por habitarem ambientes de água doce, reforçando a ausência de água salobra em depósitos do Mioceno superior da Bacia do Acre. Identificações anteriores de $P$. maculata e Aylacostoma sp. são alteradas a partir de análises biométricas e descrições da morfologia da concha. A primeira ocorrência de Sioliella nesta bacia aduz implicações paleoecológicas de modo que amplia a fauna de gastrópodes conhecida nesses depósitos e aumenta o alcance deste gênero.
\end{abstract}

Palavras-chave: Pomacea, Aylacostoma, Sioliella, Ampullariidae, Thiaridae, Cochliopidae. 


\section{INTRODUCTION}

Fossil gastropods are known in western Amazonia since the seminal studies of Conrad (1874), along with the subsequent revisions of Roxo $(1924,1937)$ and Maury (1937). Simpson (1961) and Santos \& Castro (1967), and recently Nuttall (1990) and Wesselingh et al. (2006b) also described fossil mollusks from the upper Amazonas River related to the Pebas Formation, a Miocene large lake depositional environment (Wesselingh, 2006; 2008).

In contrast to the good number of papers about sedimentology (Gingras et al., 2002; Hovikoski et al., 2008; Gross et al., 2011), palynology (Dino et al., 2012; Silveira \& Souza, 2017; da Silva-Caminha et al., 2020), and geochemistry (Kronberg et al., 1989; Vonhof et al., 1998; Bissaro-Júnior et al., 2019) of the Amazonian Miocene, there are few taxonomic surveys of mollusk fossils from the Solimões Formation in the Acre Basin.

To continue to study the fossil gastropods from western Amazonian Miocene is important because the depositional environment of the area is a matter of debate in the literature regarding intensity and duration of marine incursions (e.g. Frailey et al., 1988; Hoorn, 1993; 1994; Räsänen et al., 1995; Webb, 1995; Latrubesse et al., 1997; 2007; Lovejoy et al., 1998; Monsch, 1998; Gingras et al., 2002; Wesselingh et al., 2002; Vonhof et al., 2003; Westaway, 2006; Hovikoski et al., 2008; Gross et al., 2015; Linhares et al., 2017; Gross \& Piller, 2020; Tcheumeleu et al., 2020). Although these publications do not specifically deal with the Acre Basin, they are important papers that discuss the depositional environment of the area and contribute to a better description of the paleoenvironment. It is reasonable to say that during the western Amazonian Miocene there were some marine incursions that mixed with the predominant mega wetland environment, thus maintaining an occasionally brackish freshwater condition (Hoorn et al., 2010; Gross et al., 2011; 2013) and that the Andean orogeny influenced these landscapes variations (Shephard et al., 2010; Sacek, 2014). In this way, this paper aims to increase the knowledge of fossil gastropods from the Solimões Formation, Acre Basin. Some gastropod species from Wesselingh et al. (2006b) are revised and new assignations are proposed, new gastropods are presented, and taxonomic and paleoenvironmental attributions are herein commented.

\section{GEOLOGICAL CONTEXT}

The Acre Basin is in western Amazonia, comprising an area of about $150.000 \mathrm{~km}^{2}$ over the states of Acre and Amazonas in Brazil. The sedimentary sequences range from Paleozoic (Lower Devonian) to Cenozoic (Neogene) with 7,700 meters thickness distributed in depositional sequences (Feijó \& Souza, 1994; Cunha, 2007; Milani et al., 2007).

The first recorded and systematized study in the Acre Basin was carried out in the 1930s by researchers from the Departamento Nacional de Produção Mineral (DNPM), to investigate the possible occurrence of hydrocarbons in the border with Peru (Oliveira, 1994).
The thick sedimentary packages present in the Acre Basin are the result of the Hercynian and Andean orogenic events. Some lithostratigraphic units are identified exclusively in seismic studies, whereas outcrops and fossils are more common in higher units, especially in the Solimões Formation, dating from the Ypresian to the Neogene (da Silva et al., 2003; Cunha, 2007).

The lithostratigraphic unit known today as Solimões Formation was firstly observed by Rego (1930), and formalized by Caputo et al. (1972). Its deposition is correlated with the Pebas (Peru and Colombia), Curaray (Ecuador) and Urumaco (Venezuela) formations (Wesselingh et al., 2002; Guimarães, 2011). The Solimões Formation is described as containing a sequence of sandy and clayey rocks deposited by a fluvial and fluvial-lacustrine system, with facies associated with sandy bars and flood plains (da Silva et al., 2003; Guimarães, 2011; Medeiros, 2017). It is a formation with a wide distribution in the Amazon region, as it is registered both in the Acre and the Solimões basins.

\section{MATERIAL AND METHODS}

The fossiliferous material presented herein is composed of eleven specimens of gastropods collected in three outcrops (Figure 1). These fossils are deposited at the Laboratório de Pesquisas Paleontológicas (LPP) of the Universidade Federal do Acre (UFAC) under the identification acronym IF followed by a catalog number.

The Cachoeira do Bandeira outcrop is situated south of the state of Acre (AC), on the north bank of the Acre river,

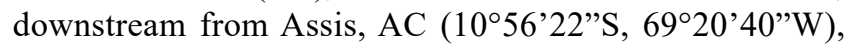
where a single specimen was collected. This outcrop was previously described by the RADAMBRASIL Project (1976) (Souza-Filho \& Guilherme, 2015), where a variety of taxa were identified, like fishes (Aguilera et al., 2008), birds (Alvarenga \& Guilherme, 2003), and crocodiles (Aureliano et al., 2015), configuring a region with good fossiliferous potential. It is associated with the South American Land Mammal Ages Huayquerian-Montehermosan (Alvarenga \& Guilherme, 2003; Latrubesse et al., 2010), thus having a late Miocene-early Pliocene age of approximately 6-9 Ma (Flynn \& Swisher III, 1995).

The Oriente outcrop is in the north of the state, on the north bank of the Purus River, downstream from Manoel Urbano, AC $\left(08^{\circ} 49^{\prime} 19^{\prime}\right.$ 'S, $\left.69^{\circ} 13^{\prime} 44^{\prime \prime} \mathrm{W}\right)$, where seven specimens were collected. According to Wesselingh et al. (2006b), the mollusks were collected in a paleosol level of alluvial sediments.

Finally, three specimens were collected by researchers from Universidade Estadual Paulista (UNESP), Universidade de São Paulo (USP), and UFAC in the location called Spot 04, which represents outcrops on the left bank downstream the Purus River, close to the city of Manoel Urbano ( $09^{\circ} 02^{\prime} 32^{\prime \prime}$, 69³4'47' W).

For the taxonomic classification of the fossils, the works of Perry (1810), Nuttall (1990), Bieler (1992), Simone \& Mezzalira (1994), Cowie (1997), Cazzaniga (2002), 


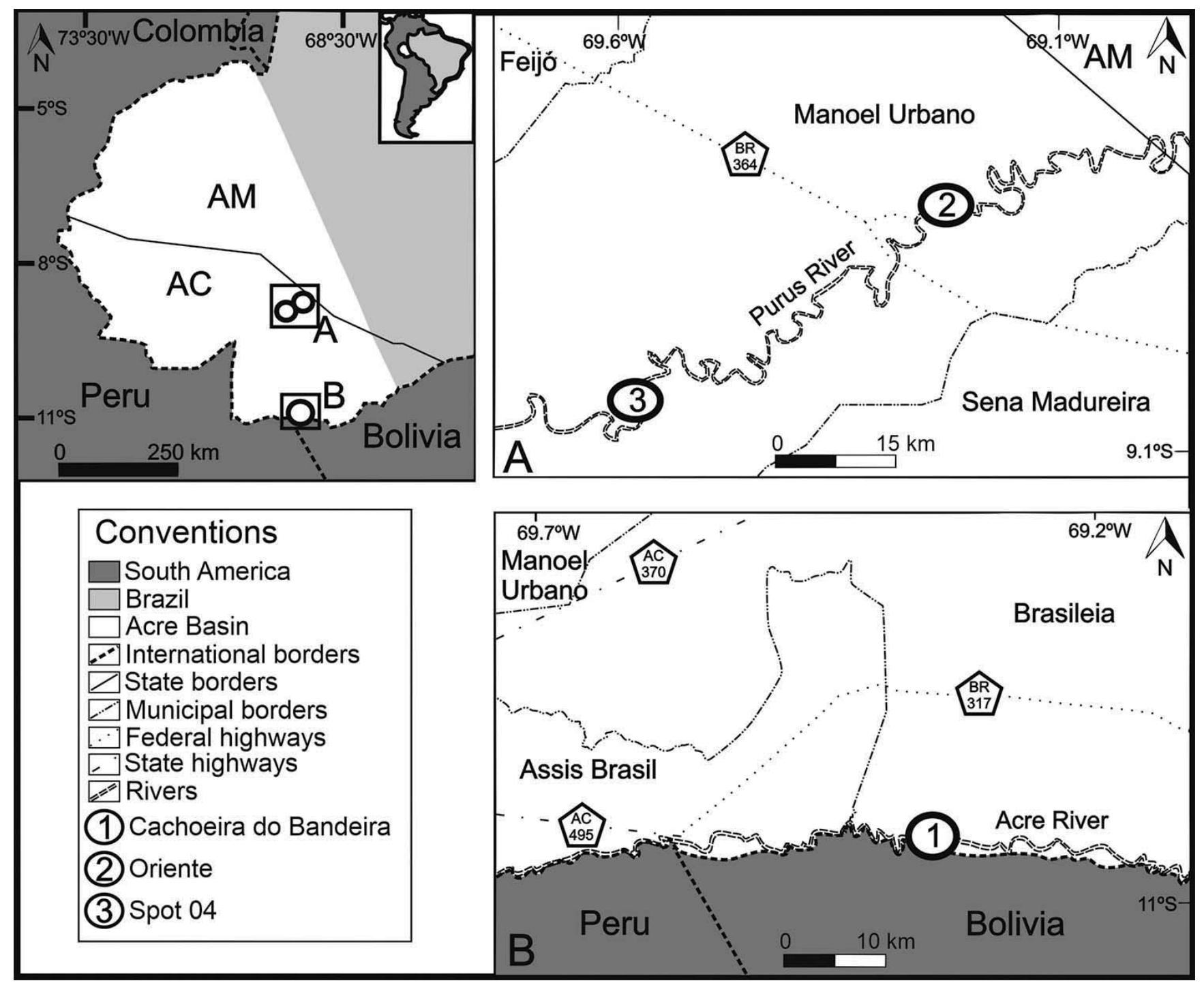

Figure 1. Fossiliferous collection sites, Solimões Formation, Acre Basin, Brazil.

Wesselingh et al. (2002), Cowie et al. (2004), Simone (2006, 2011), Wesselingh (2006), Wesselingh et al. (2006b), Hayes et al. (2012, 2015), and Pyron \& Brown (2015) were taken into consideration. The supraganeric taxonomy follows Bouchet et al. (2017).

The biometric values (Figure 2) were established by measuring the total length (TL), represented by the distance between the apex of the shell and the most distal part of the aperture, the total width (TW), defined as the maximum dimension of the aperture perpendicular to the length line, the aperture length $(\mathbf{A L})$, the aperture width $(\mathbf{A W})$, the length of the last whorl (BWL), defined as the last whorl before the aperture, the penultimate whorl length (PWL), the spire length (SL), and the spire width (SW). When a measure could not be established in a shell by preservation factors, the respective value is not quoted in the dimensions. Such shell measurements were defined by Vogler et al. (2014) in specimens of Aylacostoma; however, the same dimensions were used here also for other species. The measurements are given in millimeters. The morphological aspects of the shells were also considered. Such characteristics are related to the contours, type of aperture, and ornamentation.

\section{SYSTEMATIC PALEONTOLOGY}

\author{
Phylum MOLLUSCA Linnaeus, 1758 \\ Class GASTROPODA Cuvier, 1795 \\ Subclass CAENOGASTROPODA Cox, 1959 \\ Grade ARCHITAENIOGLOSSA Haller, 1890 \\ Superfamily AMPULLARIOIDEA Gray, 1924 \\ Family AMPULLARIIDAE Gray, 1824
}

Pomacea Perry, 1810

Type species. Pomacea maculata Perry, 1810.

Diagnosis. Shell univalve, orbicular, spire short, round, and obtuse, mouth open and divided by a circular margin from the body, beak none (Perry, 1810). 
Stratigraphic distribution. Cretaceous to Recent (Melchor et al., 2002; Martín \& Francesco, 2006; Novas et al., 2019).

\section{Pomacea maculata Perry, 1810}

(Figures 3I-J)

1856 Ampullaria amazonica Reeve, pl. 12, fig. 55, p. 13. 1856 Ampullaria haustrum Reeve, pl. 5, fig. 23, p. 6. 1856 Ampullaria imersa Reeve, pl. 11, fig. 52, p. 12. 1856 Ampullaria vermiformis Reeve, pl. 12, fig. 54, p. 13. 1857 Ampullaria castelnaudii Hupé, pl. 11, fig. 1, p. 65. 1872 Ampullaria crosseana Hidalgo, pl. 7, fig. 1, p. 142. 1889 Ampullaria georgii Williams, p. 49, no figs.

Material. IF-182.

Dimensions. TL 158.5; TW 121; AL 112.5; AW 72; BWL 107; PWL 38; SL 13.5; SW 55.5.

Locality. Cachoeira do Bandeira, Acre River, Acre State, Brazil.

Description. Shell globose. Spire short, less than a third the size of the last whorl, which is wider than it is tall. Last whorl with prominent shoulder and smooth ramp spires, impressed sutures. The shell is cracked. Aperture not preserved, only the outer lip.

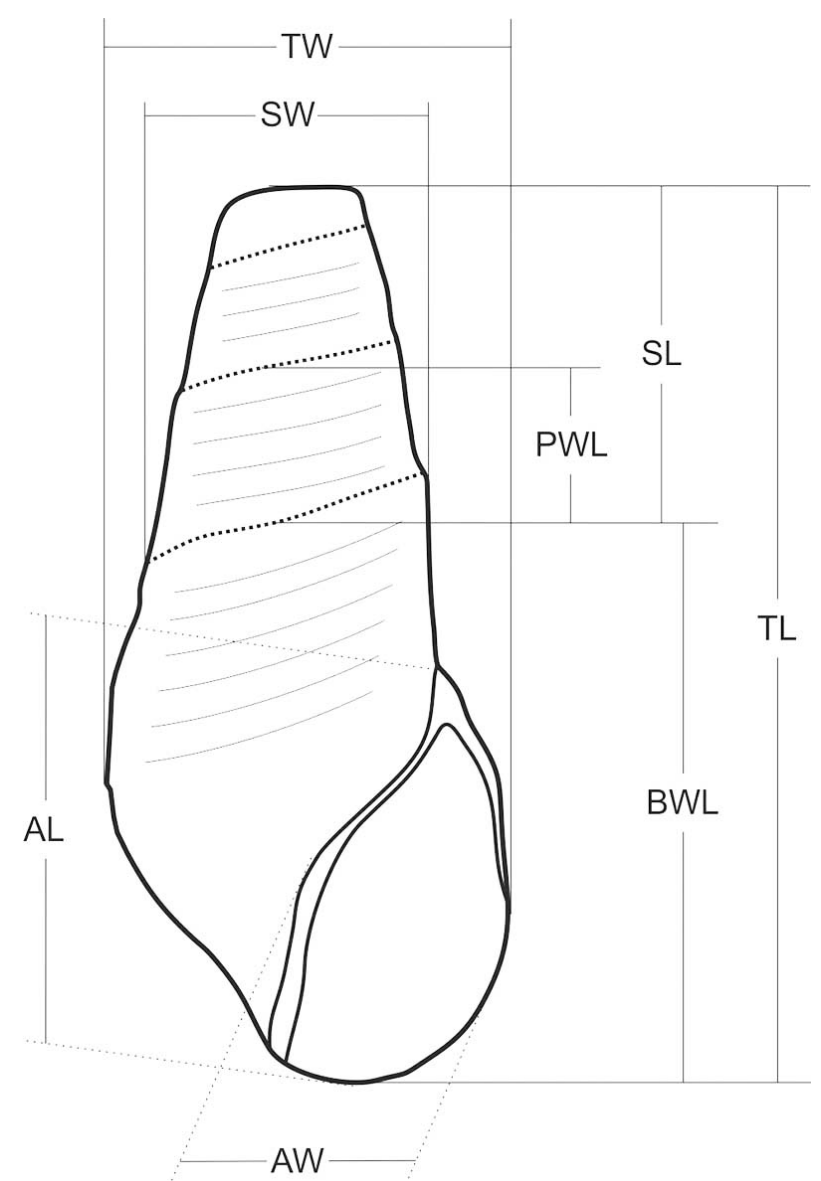

Figure 2. Shell measurements considered. Abbreviations: TL, total length; TW, total width; AL, aperture length; AW, aperture width; BWL, length of the last whorl; PWL, penultimate whorl length; SL, spire length; SW, spire width. After Vogler et al. (2014).
Remarks. This specimen was classified as 'Ampullariidae sp. 1' by Wesselingh et al. (2006b), being here restricted to Pomacea maculata due to the number of whorls (2) of the teleoconch, height of the spire, and suture of the aperture whorl. The genus Ampullaria Lamarck, 1799 was used in the literature to refer to Pomacea gastropods, but it is a junior objective synonym of Pila Röding, 1798 (Cowie, 1997). As a result, A. amazonica, A. haustrum, A. imersa, A. vermiformis, A. castelnaudii, $A$. crosseana, and $A$. georgii were listed as synonyms of $P$. maculata by Hayes et al. (2012) mostly due to size, shape, and coloration similarities with $P$. maculata.

\section{Pomacea planorbula (Philippi, 1852)}

(Figures 3A-E)

Material. IF-349.

Dimensions. TL 23; TW 27; AL 14; AW 10; BWL 20; PWL 1.5; SL 3; SW 10.

Locality. Spot 04, Purus River, Acre State, Brazil.

Description. Ampullariid discoidal, wider than tall. Spire short, less than a third the size of the last whorl, which is wider than it is tall. Last whorl with a prominent shoulder. Discoidal shell and holostomatous aperture.

Remarks. Classified as Pomacea planorbula due to its discoidal shell, characteristics of the last whorl, type of spire and aperture.

\section{Pomacea sp.}

(Figures 3F-H)

Material. IF-298.

Dimensions. TL 45; TW 44; BWL 35; PWL 5; SL 5; SW 20. Locality. Spot 04, Purus River, Acre State, Brazil.

Description. Ampullariid globose, slightly taller than wide. Spire short, less than a third the size of the last whorl, which is wider than it is tall. Last whorl with a prominent shoulder. The aperture is not preserved. The shell is cracked.

Remarks. The poor state of preservation of the shell limits a more specific classification.

Cohort SORBEOCONCHA Ponder \& Lindberg, 1997 Subcohort CERITHIIMORPHA Golikov \& Starobogatov, 1975

Superfamily CERITHIOIDEA Fleming, 1822 Family THIARIDAE Gill, 1871

$$
\text { Aylacostoma Spix, } 1827
$$

Type species. Aylacostoma glabrum Spix, 1827.

Diagnosis. Shell acicular, with pronounced ramp and shoulder developed on last whorl or so. Weak spiral sculpture, mainly of grooving tending to be concentrated on ramp. Collabral sculpture virtually absent. Aperture notched below. (Nuttall, 1990, p. 258).

Stratigraphic distribution. Upper Oligocene-lower Miocene to Recent (Wesselingh et al., 2006a). 
A

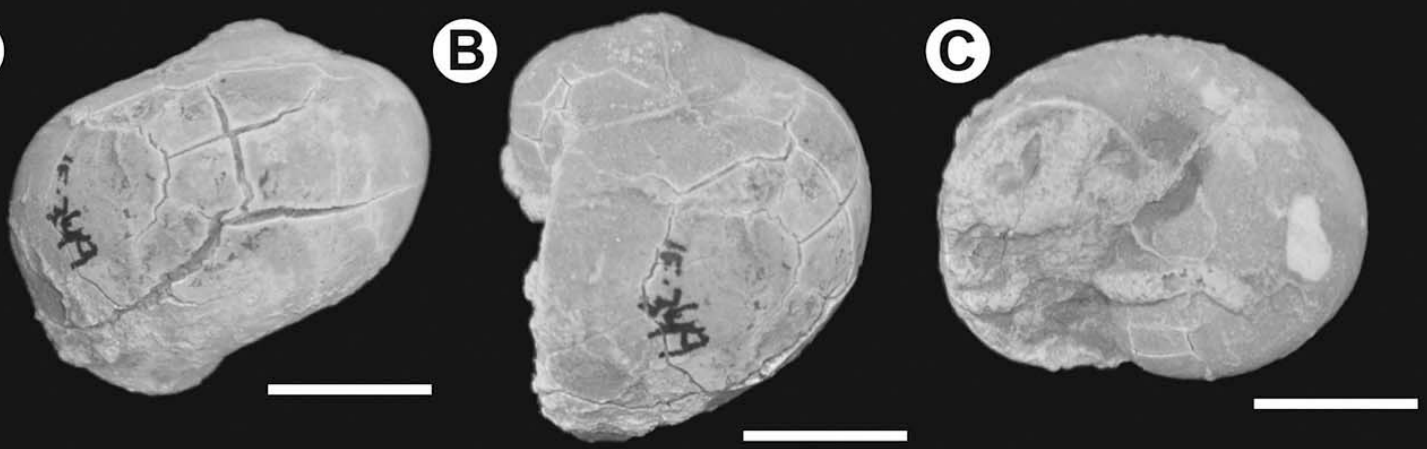

D
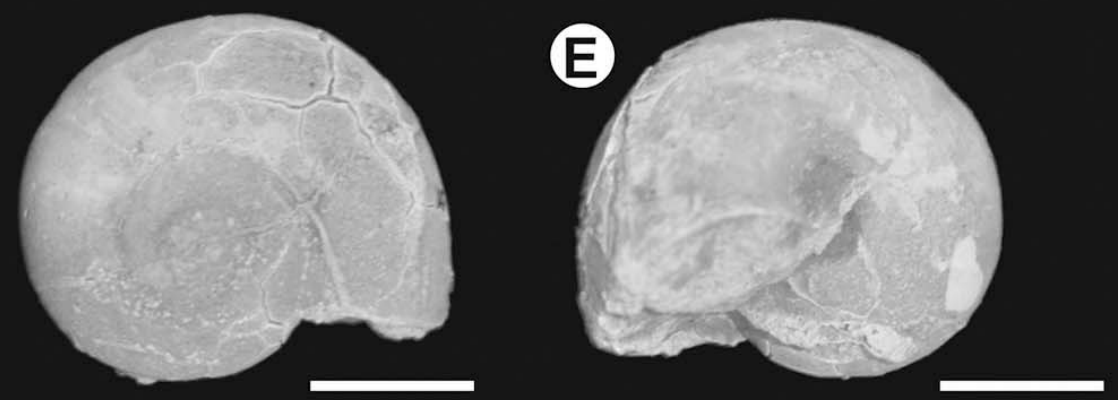

F

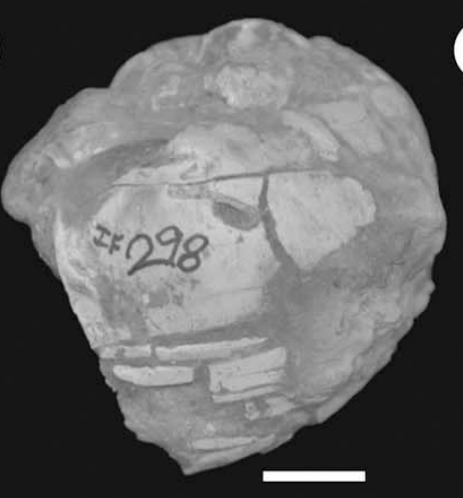

G

(1)

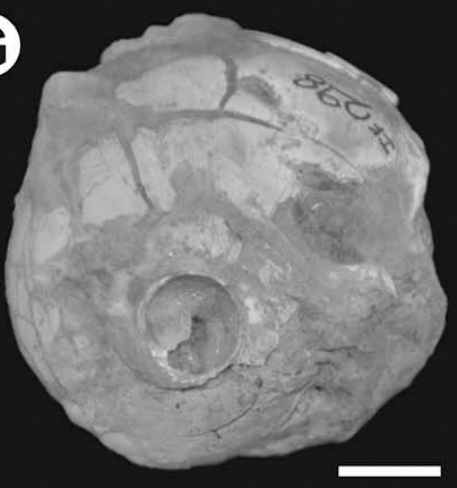

H

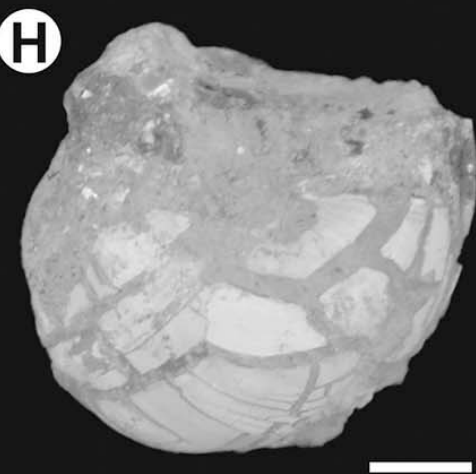

(J)

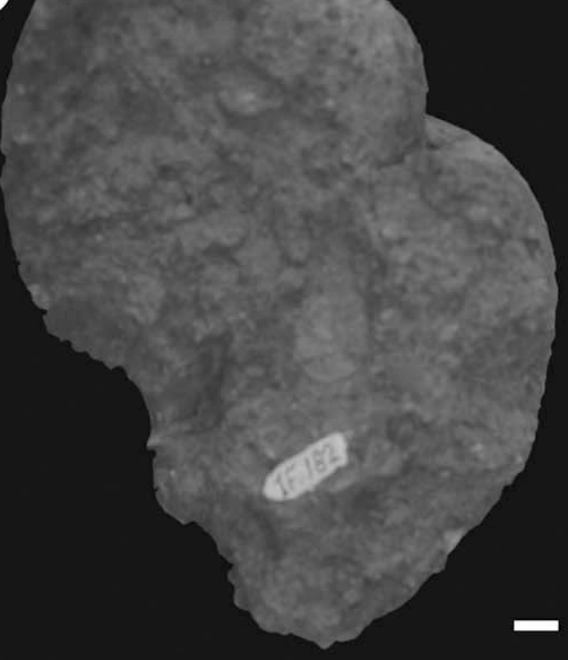

Figure 3. Miocene gastropods from the Solimões Formation, Acre Basin, Brazil. A-E, Pomacea planorbula; F-H, Pomacea sp.; I-J, P. maculata. Scale bars $=10 \mathrm{~mm}$. 
Aylacostoma sp.

(Figures 4A-G)

Material. IF-186, IF-187, IF-188, IF-189, IF-190, IF-191, IF-193.

Dimensions. IF-186: TL 18; TW 7; BWL 6; PWL 4; SL 12; SW 6. IF-187: TL 23; TW 9; BWL 7; PWL 4; SL 16; SW 7. IF-188: TL 20; TW 7; AL 5; AW 4; BWL 8; PWL 3; SL 12; SW 6. IF-189: TL 13; TW 7; AL 4; AW 5; BWL 7; PWL 2; SL 6; SW 5. IF-190: TL 12; TW 8; BWL 8; PWL 4; SL 4; SW 6. IF-191: TL 15; TW 7; AL 4; AW 3; BWL 7; PWL 3; SL 8; SW 5. IF-193: TL 14; TW 8; BWL 9; PWL 3; SL 5; SW 5.

Locality. Oriente, Purus River, Acre State, Brazil.

Description. Conical shell. The firsts whorls of the teleoconch are attached, with firmly printed sutures on the shell and aligned margins. The posterior region of the teleoconch has the most marked whorls, with a convex lateral curvature and with marginally marked sutures. The whorls gradually increase in length towards the aperture.

Remarks. Spix (in Wagner, 1827) described two species of Aylacostoma, A. glabrum and A. tuberculatum, but Wagner (1827) - who published this posthumous manuscript of Spix - changed them to Melania scalaris Wagner, 1827 and Melania tuberculata Wagner, 1827 (Cowie et al., 2004). Etheridge (1879) presents species of Melania collected in Alto Amazonas and at Javari River, and Roxo (1924) records this genus in deposits from Alto Amazonas, also in the Javari River, in Três Unidos, and in Cachoeira das Fracoas. Santos \& Castro (1967) registers Aylacostoma in Três Unidos. Finally, Wesselingh et al. (2006b) transferred all specimens referred by Roxo (1937) as Hemisinus to the Pachychilidae Troschel, 1857 genus Sheppardiconcha, based on morphological characters. Part of the material cited by Wesselingh et al. (2006b) as Sheppardiconcha is presented here as well (IF186/IF-191) and new assignations are made.

In our opinion, the Thiaridae specimens presented here are restricted to Aylacostoma in its original sense, due to the characteristics of the shell, like smooth ornamentation, not strong enough to be Sheppardiconcha, lack of the protoconch, and sutures, features seen in all specimens presented here. The IF-186, IF-187, IF-188, IF-189, IF-190 and IF-191 specimens resemble Aylacostoma tricarinata Etheridge, 1879; however, they are classified here as Aylacostoma sp., as well as IF-193 specimen, due to the lack of good morphological characters, since all the studied individuals have abrasion marks throughout the spire and lack the protoconch. The aperture is incomplete or lost, leaving only the basal contour, making it impossible to evaluate the lips or the umbilicus.

Subcohort HYPSOGASTROPODA Superfamily TRUNCATELLOIDEA Gray, 1840 Family COCHLIOPIDAE Tryon, 1866

Sioliella Haas, 1949
Type species. Sioliella effusa Haas, 1949.

Diagnosis. "Shell dextral, globose, smooth to carinate, apertural base with a kind of siphonal notch; umbilical ridge prominently developed in most species" (Wesselingh, 2000, p. 132).

Stratigraphic distribution. Miocene to Recent (Wesselingh et al., 2006a).

Sioliella sp.

(Figure 4H)

Material. IF-201.

Dimensions. TL 11; TW 9; BWL 8; PWL 2; SL 3; SW 4.

Locality. Spot 04, Purus River, Acre State, Brazil.

Description. Shell thin, smooth, just over $10 \mathrm{~mm}$ in length, robust, and coiled. Rounded ramp and shoulder. The sutures are light and shallow. Rounded and convex whorls. Aperture not preserved.

Remarks. Cochliopidae is a diverse Truncatelloidea family on the Pebas System (Wesselingh, 2006) and was recently registered on the well 1 AS 34-AM (Guimarães et al., 2018). Amazonian members of Sioliella were initially described as Ebora Conrad, 1871 (= Eubora Kadolsky, 1980) (Wesselingh, 2000). Haas (1949) included the species in his new genus Sioliella. Due to the small dimensions and the bad preservation of the shell, it is not feasible to reach a specific determination. The specimen resembles Sioliella ovata Wesselingh, 2000 due to the shape of the spire and the contour of the shoulder on the last whorl; but unfortunately, the aperture, which is a diagnostic character for this species, has not been preserved.

\section{CONCLUDING REMARKS}

The gastropod genera and species presented herein corroborates a freshwater environment for the Acre Basin deposits and peripheral areas during the late Miocene (Santos \& Castro, 1967; Vonhof et al., 2003; Westaway, 2006; Latrubesse et al., 2010; Cadena \& Casado-Ferrer, 2019; Tcheumeleu et al., 2020). It can be inferred that the Acre System (sensu Hoorn et al., 2010) was established without major influences from brackish water.

The specimen IF-182 is classified as Pomacea maculata. The IF-186, IF-187, IF-188, IF-189, IF-190, and IF-191 specimens were included in Aylacostoma sp. modifying the prior classification done by Wesselingh et al. (2006b). An individual of Sioliella sp. was identified among the studied mollusks and represents the first record of the genus for the Acre Basin.

\section{ACKNOWLEDGMENTS}

The author FNS thanks to S. Martinez and two other anonymous reviewers for the suggestions and comments, and to M. Silva for the photographs; The author ASH thanks to FAPESP (Process nº 2011/14080-0). 


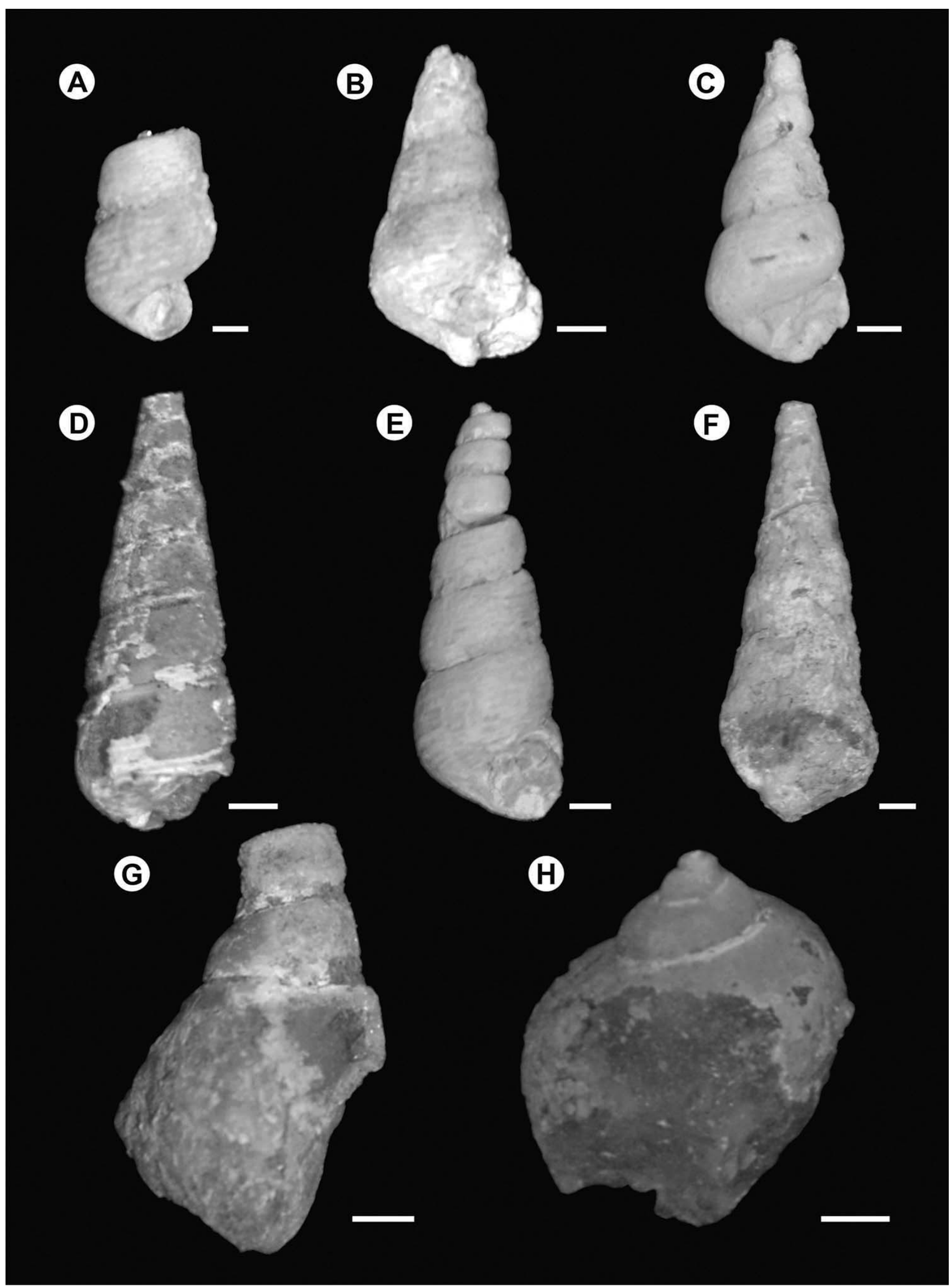

Figure 4. Miocene gastropods from the Solimões Formation, Acre Basin, Brazil. A-G, Aylacostoma sp.; H, Sioliella sp. Scale bars $=2 \mathrm{~mm}$. 


\section{REFERENCES}

Aguilera, O.A.; Bocquentin, J.; Lundberg, J.G. \& Maciente, A. 2008. A new cajaro catfish (Siluriformes: Pimelodidae: Phractocephalus) from the Late Miocene of southwestern Amazonia and its relationship to $\uparrow$ Phractocephalus nassi of the Urumaco Formation. Paläontologische Zeitschrift, 82:231-245. doi:10.1007/BF02988412

Alvarenga, H.M.F. \& Guilherme, E. 2003. The anhingas (Aves: Anhingidae) from the upper Tertiary (Miocene-Pliocene) of southwestern Amazonia. Journal of Vertebrate Paleontology, 23:614-621. doi:10.1671/1890

Aureliano, T.; Ghilardi, A.M.; Guilherme, E.; Souza-Filho, J.P.; Cavalcanti, M. \& Riff, D. 2015. Morphometry, bite-force, and paleobiology of the Late Miocene caiman Purussaurus brasiliensis. PLoS ONE, 10:e117944. doi:10.1371/journal. pone.011794

Bieler, R. 1992. Gastropod phylogeny and systematics. Annual Review of Ecology and Systematics, 23:311-338. doi:10.1146/ annurev.es.23.110192.001523

Bissaro-Júnior, M.C.; Kerber, L.; Crowley, J.L.; Ribeiro, A.M.; Ghilardi, R.P.; Guilherme, E.; Negri, F.R.; Souza-Filho, J.P. \& Hsiou, A.S. 2019. Detrital zircon U-Pb geochronology constrains the age of Brazilian Neogene deposits from Western Amazonia. Palaeogeography, Palaeoclimatology, Palaeoecology, 516:6470. doi:10.1016/j.palaeo.2018.11.032

Bouchet, P.; Rocroi, J.P.; Hausdorf, B.; Kaim, A.; Kano, Y.; Nützel, A.; Parkhaev, P.; Schrödl, M. \& Strong, E.E. 2017. Revised classification, nomenclator and typification of Gastropod and Monoplacophoran families. Malacologia, 61:1-526. doi:10.4002/040.061.0201

Cadena, E.A. \& Casado-Ferrer, I. 2019. Late Miocene freshwater mussels from the intermontane Chota Basin, northern Ecuadorean Andes. Journal of South American Earth Sciences, 89:39-46. doi:10.1016/j.jsames.2018.10.012

Caputo, M.V.; Rodrigues, R.; Vasconcelos, D.N.N. 1972. Nomenclatura estratigráfica da Bacia do Amazonas: histórico e atualização. In: CONGRESSO BRASILEIRO DE GEOLOGIA, 26, 1972. Resumos, Belém, p. 35-46.

Cazzaniga, N.J. 2002. Old species and new concepts in the taxonomy of Pomacea (Gastropoda: Ampullariidae). Biocell, 26:71-81.

Conrad, T.A. 1874. Remarks on the Tertiary clay of the Upper Amazon, with descriptions of new shells. Proceedings of the Academy of Natural Sciences of Philadelphia, 26:25-32.

Cowie, R.H. 1997. Pila Röding, 1798 and Pomacea Perry, 1810 (Mollusca, Gastropoda): proposed placement on the Official List, and Ampullariidae Gray, 1824: proposed confirmation as the nomenclaturally valid synonym of Pilidae Preston, 1915. Bulletin of Zoological Nomenclature, 54:83-88.

Cowie, R.H.; Cazzaniga, N.J. \& Glaubrecht, M. 2004. The South American Mollusca of Johann Baptist Ritter von Spix and their publication by Johann Andreas Wagner. The Nautilus, 118:71-87.

Cunha, P.R.D.C. 2007. Bacia do acre. Boletim de Geociencias Da Petrobras, 15:207-215.

da Silva-Caminha, S.A.F.; D’Apolito, C.; Jaramillo, C.; Espinosa, B.S. \& Rueda, M. 2020. Palynostratigraphy of the Ramon and Solimões formations in the Acre Basin, Brazil. Journal of South American Earth Sciences, 103:102720. doi:10.1016/j. jsames.2020.102720 da Silva, A.J.P.; Lopes, R. da C.; Vasconcelos, A.M. \& Bahia, R.B.C. 2003. Bacias Sedimentares Paleozóicas e Meso-Cenozóicas Interiores. In: L.A. Bizzi; C. Schobbenhaus; R.M. Vidotti e J.H. Gonçalves (eds.) Geologia, Tectônica e Recursos Minerais do Brasil, CPRM, p. 55-85.

Dino, R.; Soares, E.A.A.; Antonioli, L.; Riccomini, C. \& Nogueira, A.C.R. 2012. Palynostratigraphy and sedimentary facies of Middle Miocene fluvial deposits of the Amazonas Basin, Brazil. Journal of South American Earth Sciences, 34:61-80. doi:10.1016/j.jsames.2011.11.008

Etheridge, R. 1879. Notes on the Mollusca collected by C. Barrington Brown, Esq., ARSM, from the Tertiary deposits of Solimões and Javary Rivers, Brazil. Quarterly Journal of the Geological Society, 35:82-88.

Feijó, F.J. \& Souza, R.G. 1994. Bacia do Acre. Boletim de Geociencias da Petrobras, 8:9-16.

Flynn, J.J. \& Swisher, C.C. 1995. Cenozoic South American Land Mammal Ages: correlation to global geochronologies. SEPM Special Publication, 54:317-334. doi:10.2110/pec.95.04.0317

Frailey, C.D.; Lavina, E.L.; Rancy, A. \& Souza-Filho, J.P. 1988. A proposed Pleistocene/Holocene lake in the Amazon basin and its significance to Amazonian geology and biogeography. Acta amazonica, 18:119-143.

Gingras, M.K.; Räsänen, M. \& Ranzi, A. 2002. The significance of bioturbated inclined heterolithic stratification in the southern part of the Miocene Solimoes Formation, Rio Acre, Amazonia Brazil. Palaios, 17:591-601. doi:10.1669/08831351(2002)017<0591:TSOBIH>2.0.CO;2

Gross, M. \& Piller, W.E. 2020. Saline waters in Miocene western Amazonia - an alternative view. Frontiers in Earth Science, 8:1-15. doi:10.3389/feart.2020.00116

Gross, M.; Piller, W.E.; Ramos, M.I. \& Paz, J.D.S. 2011. Late Miocene sedimentary environments in south-western Amazonia (Solimões Formation; Brazil). Journal of South American Earth Sciences, 32:169-181. doi:10.1016/j.jsames.2011.05.004

Gross, M.; Ramos, M.I.F.; Caporaletti, M. \& Piller, W.E. 2013. Ostracods (Crustacea) and their palaeoenvironmental implication for the Solimões Formation (late Miocene; western Amazonia/ Brazil). Journal of South American Earth Sciences, 42:216-241. doi:10.1016/j.jsames.2012.10.002

Gross, M.; Ramos, M.I.F. \& Piller, W.E. 2015. A minute ostracod (Crustacea: Cytheromatidae) from the Miocene Solimões Formation (western Amazonia, Brazil): evidence for marine incursions? Journal of Systematic Palaeontology, 14:581-602. doi:10.1080/14772019.2015.1078850

Guimarães, L.I. de A. 2011. Estudo sistemático de gastrópodes neógenos, com ênfase no gênero Tryonia (Stimpson, 1865), Formação Solimões, Estado do Amazonas. Universidade Federal do Pará, M.Sc. thesis, 101 p.

Guimarães, L.I. de A.; Ramos, M.I.F. \& Simone, L.R.L. 2018. New records of Tryonia (Gastropoda, Cochliopidae) from the Mio-Pliocene Solimões Formation (State of Amazonas), Brazil. Revista Brasileira de Paleontologia, 21:255-264. doi:10.4072/ rbp.2018.3.06

Haas, F. 1949. On fresh water mollusks from the Amazonian region. Anales Instituto Biologico del Universidad de Mexico, 20:301-314.

Hayes, K.A.; Cowie, R.H.; Thiengo, S.C. \& Strong, E.E. 2012. Comparing apples with apples: clarifying the identities of two highly invasive Neotropical Ampullariidae (Caenogastropoda). Zoological Journal of the Linnean Society, 166:723-753. doi:10.1111/j.1096-3642.2012.00867.x 
Hayes, K.A. et al. 2015. Insights from an integrated view of the biology of apple snails (Caenogastropoda: Ampullariidae). Malacologia, 58:245-302. doi:10.4002/040.058.0209

Hoorn, C. 1993. Marine incursions and the influence of Andean tectonics on the Miocene depositional history of northwestern Amazonia: results of a palynostratigraphic study. Palaeogeography, palaeoclimatology, palaeoecology, 105:267309. doi:10.1016/0031-0182(93)90087-Y

Hoorn, C. 1994. An environmental reconstruction of the palaeoAmazon river system (Middle-Late Miocene, NW Amazonia). Palaeogeography, Palaeoclimatology, Palaeoecology, 112:187238. doi:10.1016/0031-0182(94)90074-4

Hoorn, C. et al. 2010. Amazonia through time: Andean uplift, climate change, landscape evolution, and biodiversity. Science, 330:927-931. doi:10.1126/science.1194585

Hovikoski, J.; Räsänen, M.; Gingras, M.; Ranzi, A. \& Melo, J. 2008. Tidal and seasonal controls in the formation of Late Miocene inclined heterolithic stratification deposits, western Amazonian foreland basin. Sedimentology, 55:499-530. doi:10.1111/j.13653091.2007.00907.x

Kadolsky, D. 1980. On the taxonomic position, the species and the paleoecological significance of the genera Eubora, Toxosoma and Littoridina (?) in the Pliocene Pebas Formation of the Upper Amazon region (Gastropoda: Prosobranchia). The Veliger, 22:364-375.

Kronberg, B.I.; Franco, J.R.; Benchimol, R.E.; Hazenberg, G.; Doherty, W. \& Vandervoet, A. 1989. Geochemical variations in Solimões Formation sediments (Acre Basin, Western Amazonia). Acta Amazonica, 19:319-333.

Latrubesse, E.M.; Bocquentin, J.; Santos, J.C.R. \& Ramonell, C.G. 1997. Paleoenvironmental model for the Late Cenozoic of southwestern Amazonia: paleontology and geology. Acta Amazonica, 27:103-118.

Latrubesse, E.M.; Cozzuol, M.; da Silva-Caminha, S.A.F.; Rigsby, C.A.; Absy, M.L. \& Jaramillo, C. 2010. The Late Miocene paleogeography of the Amazon Basin and the evolution of the Amazon River system. Earth-Science Reviews, 99:99-124. doi:10.1016/j.earscirev.2010.02.005

Latrubesse, E.M.; da Silva-Caminha, S.A.F.; Cozzuol, M. \& Absy, M.L. 2007. Late Miocene continental sedimentation in southwestern Amazonia and its regional significance: biotic and geological evidence. Journal of South American Earth Sciences, 23:61-80. doi:10.1016/j.jsames.2006.09.021

Linhares, A.P.; de Souza Gaia, V.D.C. \& Ramos, M.I.F. 2017. The significance of marine microfossils for paleoenvironmental reconstruction of the Solimões Formation (Miocene), western Amazonia, Brazil. Journal of South American Earth Sciences, 79:57-66. doi:10.1016/j.jsames.2017.07.007

Lovejoy, N.R.; Bermingham, E. \& Martin,A.P. 1998. Marine incursion into South America. Nature, 396:421-422. doi:10.1038/24757

Martín, P.R. \& Francesco, C.G. de. 2006. Fossil record of Pomacea (Caenogastropoda: Ampullariidae) in Argentina and its paleoenvironmental implications. Biocell, 30:337-343.

Maury, C.J. 1937. Argillas fossiliferas do pliocenio do território do Acre. Boletim do Serviço Geológico e Mineralógico do Brasil, $31 \mathrm{p}$.

Medeiros, C.G. 2017. Ostracodes da Formação Solimões, Brasil: contribuição à bioestratigrafia do Neógeno da Amazônia. Programa de Pós-Graduação em Geologia, Universidade de Brasília, M.Sc. thesis, 78 p.

Melchor, R.N.; Genise, J.F. \& Miquel, S.E. 2002. Ichnology, sedimentology and paleontology of Eocene calcareous paleosols from a palustrine sequence, Argentina. Palaios, 17:16-35. doi:10.1669/0883-1351(2002)017<0016:ISAPOE > 2.0.CO;2

Milani, E.J.; Rangel, H.D.; Bueno, G.V.; Stica, J.M.; Winter, W.R.; Caixeta, J.M. \& Da Cruz Pessoa Neto, O. 2007. Bacias sedimentares brasileiras - Cartas estratigráficas. Boletim de Geociencias Da Petrobras, 15:183-205.

Monsch, K.A. 1998. Miocene fish faunas from the northwestern Amazonia basin (Colombia, Peru, Brazil) with evidence of marine incursions. Palaeogeography, Palaeoclimatology, Palaeoecology, 143:31-50. doi:10.1016/S00310182(98)00064-9

Novas, F.E. et al. 2019. Paleontological discoveries in the Chorrillo Formation (upper Campanian-lower Maastrichtian, Upper Cretaceous), Santa Cruz Province, Patagonia, Argentina. Revista del Museo Argentino de Ciencias Naturales, Nueva Serie, 21:217-293. doi:10.22179/REVMACN.21.655

Nuttall, C.P. 1990. A review of the Tertiary non-marine molluscan faunas of the Pebasian and other inland basins of north-western South America. Bulletin - British Museum (Natural History), Geology Series, 45:165-371.

Oliveira, C.M.M. 1994. Estilos estruturais e evolução tectônica da Bacia do Acre. Departamento de Geologia, Universidade Federal de Ouro Preto, M.Sc. thesis, 225 p.

Perry, G. 1810. Arcana. Museum of Natural History. London, James Stratford, $320 \mathrm{p}$.

Pyron, M. \& Brown, K.M. 2015. Introduction to Mollusca and the class Gastropoda. In: J.H. Thorp \& D.C. Rogers (eds.) Thorp and Covich's Freshwater Invertebrates: ecology and general biology, Academic Press, p. 383-421. doi:10.1016/B978-0-12385026-3.00018-8

Räsänen, M.E.; Linna, A.M.; Santos, J.C. \& Negri, F.R. 1995. Late Miocene tidal deposits in the Amazonian foreland basin. Science, 269:386-390. doi:10.1126/science.269.5222.386

Rego, L.F.M. 1930. Notas sobre a Geologia do território do Acre e da Bacia do Javari. Manaus, Departamento Nacional da Produção Mineral, Cezar \& Cavalcante e Cia, 45 p.

Roxo, M.G.O. 1924. Breve notícia sobre os fósseis terciários do Alto Amazonas. Serviço Geológico e Mineralógico do Brasil, 11:41-53.

Roxo, M.G.O. 1937. Fósseis pliocenios do Rio Juruá, Estado do Amazonas. Departamento de Geologia e Mineralogia. Notas Preliminares, 9:4-10.

Sacek, V. 2014. Drainage reversal of the Amazon River due to the coupling of surface and lithospheric processes. Earth and Planetary Science Letters, 401:301-312. doi:10.1016/j. epsl.2014.06.022

Santos, M.E.C.M. \& Castro, J.S. 1967. Moluscos cenozoicos de água doce do Alto Amazonas. Atas do Simpósio sobre a Biota Amazônica, 1:411-423.

Shephard, G.E.; Müller, R.D.; Liu, L. \& Gurnis, M. 2010. Miocene drainage reversal of the Amazon River driven by plate-mantle interaction. Nature Geoscience, 3:870-875. doi:10.1038/ NGEO1017

Silveira, R.R. \& Souza, P.A. 2017. Palinoestratigrafia da Formação Solimões na região do Alto Solimões (Atalaia do Norte e Tabatinga), Amazonas, Brasil. Geociências, 36:100-117. doi:10.5016/geociencias.v36i1.12299

Simone, L.R.L. 2006. Land and freshwater molluscs of Brazil. São Paulo, EGP, Fapesp, 390 p.

Simone, L.R.L. 2011. Phylogeny of the Caenogastropoda (Mollusca), based on comparative morphology. Arquivos de Zoologia, 42:161-323. 
Simone, L.R.L. \& Mezzalira, S. 1994. Fossil Molluscs of Brazil. São Paulo, Governo do Estado de São Paulo, 202 p.

Simpson, G.G. 1961. The supposed Pliocene Pebas beds of the upper Juruá River, Brazil. Journal of Paleontology, 35:620-624.

Souza-Filho, J.P. \& Guilherme, E. 2015. A paleontologia no Estado do Acre. In: CPRM (ed.) Geodiversidade do Estado do Acre, CPRM, p. 147-158.

Tcheumeleu, A.F. et al. 2020. Depositional environments and landscapes of the upper Miocene Ipururo Formation at Shumanza, Subandean Zone, northern Peru. Palaeobiodiversity and Palaeoenvironments, 100:719-735. doi:10.1007/s12549019-00400-8

Vogler, R.E.; Beltramino, A.A.; Peso, J.G. \& Rumi, A. 2014. Threatened gastropods under the evolutionary genetic species concept: redescription and new species of the genus Aylacostoma (Gastropoda: Thiaridae) from High Paraná River (ArgentinaParaguay). Zoological Journal of the Linnean Society, 172:501520. doi:10.1111/zoj.12179

Vonhof, H.B.; Wesselingh, F.P. \& Ganssen, G.M. 1998. Reconstruction of the Miocene western Amazonian aquatic system using molluscan isotopic signatures. Palaeogeography, Palaeoclimatology, Palaeoecology, 141:85-93. doi:10.1016/ S0031-0182(98)00010-8

Vonhof, H.B.; Wesselingh, F.P.; Kaandorp, R.J.G.; Davies, G.R.; van Hinte, J.E.; Guerrero, J.; Räsänen, M.; Romero-Pittman, L. \& Ranzi, A. 2003. Paleogeography of Miocene western Amazonia: isotopic composition of molluscan shells constrains the influence of marine incursions. Geological Society of America Bulletin, 115:983-993. doi:10.1130/B25058.1

Wagner, J.A. 1827. Testacea fluviatilia quae in itinere per Brasiliam annis MDCCCXVII-MDCCCXX jussu et auspiciis Maximiliani Josephi I. Bavariae regis augustissimi suscepto collegit et pingenda curavit Dr. J. B. de Spix, quondam ordinis regii coronas
Bavaricse civilis eques, academies scientarum Bavaricas socius ordinarius, musei regii zoologici, zootomici et ethnographici conservator rel. Munich, C. Wolf, $36 \mathrm{p}$.

Webb, S.D. 1995. Biological implications of the middle Miocene Amazon seaway. Science, 269:361-363. doi:10.1126/ science.269.5222.361

Wesselingh, F.P. 2000. On relict hydrobiid species in Brazilian Amazonia (Gastropoda, Prosobranchia, Hidrobiidae). Basteria, 64:129-136.

Wesselingh, F.P. 2006. Miocene long-lived lake Pebas as a stage of mollusc radiations, with implications for landscape evolution in western Amazonia. Scripta Geologica, 133:1-17.

Wesselingh, F.P. 2008. Molluscan radiations and landscape evolution in Miocene. Department of Biology, University of Turku, Ph.D. thesis, $41 \mathrm{p}$.

Wesselingh, F.P.; Anderson, L.C. \& Kadolsky, D. 2006a. Molluscs from the Miocene Pebas Formation of Peruvian and Colombian Amazonia. Scripta Geologica, 133:19-290.

Wesselingh, F.P.; Ranzi, A. \& Räsänen, M.E. 2006b. Miocene freshwater Mollusca from western Brazilian Amazonia. Scripta Geologica, 133:419-437.

Wesselingh, F.P.; Räsänen, M.E.; Irion, G.; Vonhof, H.B.; Kaandorp, R.; Renema, W.; Romero-Pittman, L. \& Gingras, M. 2002. Lake Pebas: a palaeoecological reconstruction of a Miocene, longlived lake complex in western Amazonia. Cainozoic Research, 1:35-81.

Westaway, R. 2006. Late Cenozoic sedimentary sequences in Acre state, southwestern Amazonia: fluvial or tidal? Deductions from the IGCP 449 fieldtrip. Journal of South American Earth Sciences, 21:120-134. doi:10.1016/j.jsames.2005.08.004

Received in 17 February, 2021; accepted in 29 April, 2021. 